\title{
Knockdown of Nogo gene by short hairpin RNA interference promotes functional recovery of spinal cord injury in a rat model
}

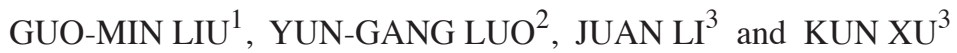

\author{
Departments of ${ }^{1}$ Orthopedics and ${ }^{2}$ Stomatology, The Second Hospital of Jilin University, Changchun, Jilin 130041; \\ ${ }^{3}$ Department of Preventive Medicine, College of Public Health, Jilin University, Changchun, Jilin 130021, P.R. China
}

Received March 29, 2015; Accepted February 1, 2016

DOI: $10.3892 / \mathrm{mmr} .2016 .5072$

\begin{abstract}
The specific myelin component Nogo protein is one of the major inhibitory molecules of spinal cord axonal outgrowth following spinal cord injury. The present study aimed to investigate the effects of silencing Nogo protein with shRNA interference on the promotion of functional recovery in a rat model with spinal cord hemisection. Nogo-A short hairpin RNAs (Nogo shRNAs) were constructed and transfected into rats with spinal cord hemisection by adenovirus-mediated transfection. Reverse transcription-polymerase chain reaction and western blotting were performed to analyze the expression of Nogo-A and Growth Associated Protein 43 (GAP-43). In addition, Basso Beattie Bresnahan (BBB) scores were used to assess the functional recovery of rats following spinal cord injury. The results demonstrated that expression of the Nogo-A gene was observed to be downregulated following transfection and GAP-43 expression was observed to increase. The BBB scores were increased following treatment with Nogo shRNAs, indicating functional recovery of the injured nerves. Thus, Nogo-A shRNA interference can knockdown Nogo gene expression and upregulate GAP-43 to promote the functional recovery of spinal cord injury in rats. This finding may advance progress toward assisting the regeneration of injured neurons through the use of Nogo-A shRNA.
\end{abstract}

\section{Introduction}

Spinal cord injury (SCI) is a devastating clinical condition for which there is currently no fully restorative treatment. Following SCI, the resulting scar tissue and myelin debris can produce a hostile environment in which neurite outgrowth and axonal regeneration is hampered by the limited intrinsic regenerative capacity of injured neurons, due to the lack of

Correspondence to: Professor Yun-Gang Luo, Department of Stomatology, The Second Hospital of Jilin University, 218 Ziqiang Street, Changchun, Jilin 130041, P.R. China

E-mail: luoygjlu@sina.com

Key words: Nogo, Growth Associated Protein 43, small hairpin RNA, spinal cord injury, neural regeneration neurotrophic support and the presence of growth inhibitory molecules in myelin $(1,2)$. Specific myelin components, such as myelin-associated glycoprotein (MAG) and the C-terminal of Nogo-A (Nogo-66), are major inhibitory molecules of spinal cord repair after SCI $(3,4)$.

Nogo protein is a central myelin-derived proteins expressed in the white matter of central neural system (CNS), and has been confirmed to block axon regeneration following injury (5). Three isoforms (Nogo-A, -B, and -C) are generated through alternative splicing and differential promoter usage from a single Nogo gene. The inhibitory action of the Nogo protein is dependent on the Nogo-66 domain, which is present in all three isoforms. Nogo-66 is a 66-amino-acid sequence between $\mathrm{N}$ - and $\mathrm{C}$-terminals. Nogo-A exerts its inhibitory effects by binding to the Nogo receptor via the Nogo-66 domain. Studies have shown that the Nogo-66 high-affinity receptor $(\mathrm{NgR})$ is a common receptor of Nogo, MAG and oligodendrocyte myelin glycoprotein (OMgp) (6-14). The $\mathrm{NgR}$ is a member of a family of three CNS-enriched glycosyl phosphatidylinositol-linked proteins (6-8). NgR functions as the ligand binding component of a tripartite receptor system consisting of Lingo-1 and tumour necrosis factor (TNF) receptor family members, p75NTR or TROY (9). Inhibition of $\mathrm{NgR}$ with function-blocking antibodies or short hairpin RNA interference (shRNA)-mediated knockdown have been reported to demonstrate that $\mathrm{NgR}$ is essential for Nogo66, MAG and OMgp inhibitory effects (10-12). NgR mRNA is detected in numerous types of neurons in the CNS and distribution of $\mathrm{NgR}$ protein is consistent with its mRNA $(13,14)$. The expression of myelin inhibitors or receptor-related proteins can be knocked down by RNA interference to reduce neuronal apoptosis and promote axonal regeneration after injury $(15,16)$.

Growth Associated Protein 43 (GAP-43), a plasticity and growth protein, is expressed at high levels in neuronal growth cones during development and axonal regeneration $(17,18)$. GAP-43 is a crucial component of the axon and presynaptic terminal, and its nonsense mutation causes defects in motor axon outgrowth and pathfinding (19).

A novel therapeutic strategy is required for neuron regeneration and SCI repair. The aim of the present study was to establish an efficient and highly specific shRNA expression and delivery system to knock down the Nogo gene and to detect effects of the Nogo shRNA system on SCI repair in a rat model. 


\section{Materials and methods}

Animals. Sprague Dawley rats ( $\mathrm{n}=40$; age, 2-3 weeks) the Basic Medicine Animal Laboratory of Jilin University were housed at a room temperature of $22 \pm 2^{\circ} \mathrm{C}$ with a 12 -h dark:light cycle and free access to food and water. The present study was approved by the Jilin University Animal Ethics Committee (Changchun, China).

Preparation of Nogo-A shRNA. The Nogo-66 gene has 66 amino acids between two transmembrane regions of Nogo proteins. The expression of Nogo-66 has a strong inhibitory effect on CNS regeneration (20). Two specific shRNA sequences were designed to target the cDNA sequence of Nogo-66 (1024-1089 amino acid fragment) and the primers were as follows: Sense, 5'-GGG CGT GAT CCA GGC TATCTT-3' and antisense, 5'-GAT AGC CTG GAT CAC GCCCTT-3'; sense 5'-GGC CAC CCA TTC AGG GCATTT-3' and antisense, 5'-ATG CCC TGA ATG GGT GGCCTT-3'. Non-effective scrambled shRNA was used as a negative control, and sequences were as follows: Sense, 5'-GGC GGT AGT CAC GGT CATCTT-3' and antisense, 5'-GAT GTG ACC GTG ACT ACC GCCTT-3'. The pShuttle-U6 (Department of Immunology, Jilin University School of Medicine, Jilin, China) was used as a template for polymerase chain reaction (PCR). The upstream primers targeting the U6 promoter and downstream primers with a Nogo-A gene reverse complementary target sequence were synthesized by Sangon Bioengineering, Inc. (Shanghai, China). The sequences were as follows: Upstream, 5'-CTCGAGCCCCAGTGGAAAGACGCG-3' for U6F and downstream, 5'-GGA TCC AAA AAA GAT AGC CTG GAT CAC GCC CTT CAA GCT TCA AGG GCG TGA TCC AGG CTA TCG GTG TTT CGT CCT TTC CACAA-3'; 5'-GGA TCC AAA AAA ATG CCC TGA ATC CCT GGC CTT CAA GCT TCA AGG CCA CCC ATT CAG GGC ATG GTG TTT CGT CCT TTC CACAA-3'; and 5'-GGA TCC AAA AAA GAT GTG ACC GTG ACT ACC GCC TCA AGC TTC GGC GGT AGT CAC GGT CAT CTT GGT GTT TCG TCC TTT CCA CAA-3' for primers of hairpins 1,2 and 3, respectively. The PCR systems were composed of $1 \mu \mathrm{l}$ pShuttle-U6 (100 ng/ $\mu \mathrm{l})$, $2.5 \mu 1 \mathrm{U} 6 \mathrm{~F}$ (10 pmol $/ \mu 1), 2.5 \mu 1$ hairpins (10 pmol $/ \mu \mathrm{l}), 3 \mu 1$ dNTP $(2.5 \mathrm{mmol} / \mathrm{l}), 5 \mu \mathrm{l} 10 \mathrm{X}$ Buffer, $3 \mu \mathrm{l} \mathrm{MgCl}_{2}, 0.5 \mu \mathrm{l}$ Taq DNA polymerase, $0.1 \mu \mathrm{l}$ Pfu DNA polymerase, $2 \mu \mathrm{l}$ DMSO and double distilled $\mathrm{H}_{2} \mathrm{O}$ up to $50 \mu \mathrm{l}$. The PCR cycling conditions were as follows: $94^{\circ} \mathrm{C}$ for $5 \mathrm{~min} ; 94^{\circ} \mathrm{C} 30 \mathrm{sec}, 55^{\circ} \mathrm{C}$ for $30 \mathrm{sec}$, $72^{\circ} \mathrm{C}$ for $1 \mathrm{~min}, 30$ cycles and $72^{\circ} \mathrm{C}$ for final extension. The PCR products that were amplified using the Bio-Rad T100 thermocycler (Bio-Rad Laboratories, Shanghai, China) were named U6shNogo1, U6shNogo2, U6shNogo3 and U6shNogo3 containing. Scrambled shRNA was used as the negative control. The U6shNogos were ligated into the $\mathrm{pUCm}-\mathrm{T}$ vector (Bio Basic Inc., Markham, ON, Canada), and the ligation products were transfected into E. coli DH5a competent cells. The plasmids were extracted and purified using an Aurum Plasmid Mini kit (cat no. 732-6400, Bio-Rad Laboratories). U6shNogos were cut from the T-vector with EcoRI and SalI, and then cloned into the AdMaxTM adenovirus shuttle plasmids pDC316 (Microbix Biosystems Inc., Toronto, ON, Canada), to construct the pDCU6shNogo1, pDCU6shNogo2 and pDCU6shNogo3 (with the scrambled sequence as the negative control) plasmids. The fragment of interest was cut by EcoRI and SalI restriction enzymes for identification. AdMax Systems (Microbix Biosystems Inc., Toronto, ON, Canada) were used as the adenovirus packaging system to package the recombinant pDCU6shNogos, and the resulting recombinant virus (rAdUNogos) was a replication deficient adenovirus due to missing E1/E3 regions.

Interference of the endogenous Nogo gene by adenovirus-mediated Nogo shRNA transfection via local injection in SCI model rats. Sprague Dawley rats $(\mathrm{n}=40)$ underwent spinal cord hemisection for modeling of SCI according to the methods of previous studies (21-24). After 7 days, transfection of the recombinant adenovirus carrying pDCU6shNogos into SCI rats was performed by direct local injection of $5 \mu \mathrm{l}$ rAdUNogos containing $10 \mu \mathrm{g}$ Nogo shRNA into the spinal cord. The rats were divided randomly into four separate groups as follows: Group A, $10 \mu \mathrm{g}$ shRNA Nogol (rAdUshNogo1); group B, $10 \mu \mathrm{g}$ shRNA Nogo2 (rAdUshNogo2); group C, $10 \mu \mathrm{g}$ shRNA Nogo3 (rAdUshNogo3 containing the chaotic sequence) served as the negative control; and group D, model control, saline containing $10 \mu \mathrm{g}$ empty adenoviral vector.

At 1, 2, 3, 4, 5, 6, 7, 8, 9 and 10 days after injection, the animals in each group were narcotized with sodium pentobarbital (30-40 mg/kg; Sigma-Aldrich, St. Louis, MO, USA) and sacrificed by cervical dislocation.

Reverse transcription-quantitative PCR (RT-qPCR). Total RNA was extracted from the spinal cord at the location of the injury 3 days subsequent to injection. Nogo mRNA was detected by RT-qPCR. Briefly, total RNA was transcribed into cDNAs. PCR amplification was performed using cDNA as the template. Nogo-A primers were as follows: Sense, 5'-TCA AAG GTG ACT GAG GCAGC-3' and antisense, 5'-ACT GGG CTG CAC TAC AGAAG-3'. Primers for the internal reference, GAPDH were as follows: Sense, 5'-GGG CCA AAA GGG TCA TCATC-3' and antisense, 5'-AAC CTG GTC CTC AGT GTAGC-3'. The PCR system of $30 \mu \mathrm{l}$ was composed $2 \mu \mathrm{l}$ of the cDNA template $(100 \mathrm{ng} / \mu \mathrm{l}), 3 \mu \mathrm{l}$ 10X buffer, $0.5 \mu 1 \mathrm{dNTP}$ (10 mmol/l), $0.5 \mu 1 \mathrm{Taq}$ DNA polymerase, $3 \mu \mathrm{l} \mathrm{MgCl}_{2}(25 \mathrm{mmol} / \mathrm{l}), 1 \mu \mathrm{l}$ primers (10 pmol/l) for each, double distilled $\mathrm{H}_{2} \mathrm{O}, 19 \mu \mathrm{l}$. The PCR thermocycling conditions were as follows: $94^{\circ} \mathrm{C}$ for $1 \mathrm{~min} ; 94^{\circ} \mathrm{C} 30 \mathrm{sec}, 55^{\circ} \mathrm{C}$ for $45 \mathrm{sec}, 72^{\circ} \mathrm{C}$ for $1 \mathrm{~min}, 30$ cycles and $72^{\circ} \mathrm{C}$ for $3 \mathrm{~min}$ for the final extension. The PCR products were separated on a $1 \%$ agarose gel.

Western blotting. The Nogo-A protein expression levels of each group were detected by western blotting 3 days after injection. GAP-43 protein expression levels in the shRNA Nogol group and the model control 1, 2, 3, 4, 5, 6, 7, 8, 9 and 10 days after injection were also determined by western blotting. The procedures were performed according to the manufacturer's protocol (Thermo Scientific Pierce Fast Western Blot kit, ECL substrate; cat no. 35050; Thermo Fisher Scientific, Inc., Waltham, MA, USA) as described previously (25). Briefly, the spinal cord tissues were homogenated and lysed with radioimmunoprecipitation assay buffer. Proteins were separated on an $10 \%$ SDS-PAGE gel and electroblotted onto 


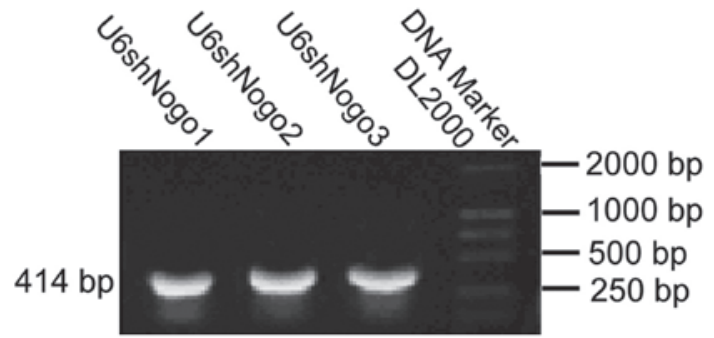

Figure 1. Polymerase chain reaction products of U6shNogos. Lane 1, U6shNogo1; lane 2, U6shNogo2; lane 3, U6shNogo3; lane 4, DNA marker (DL2000).

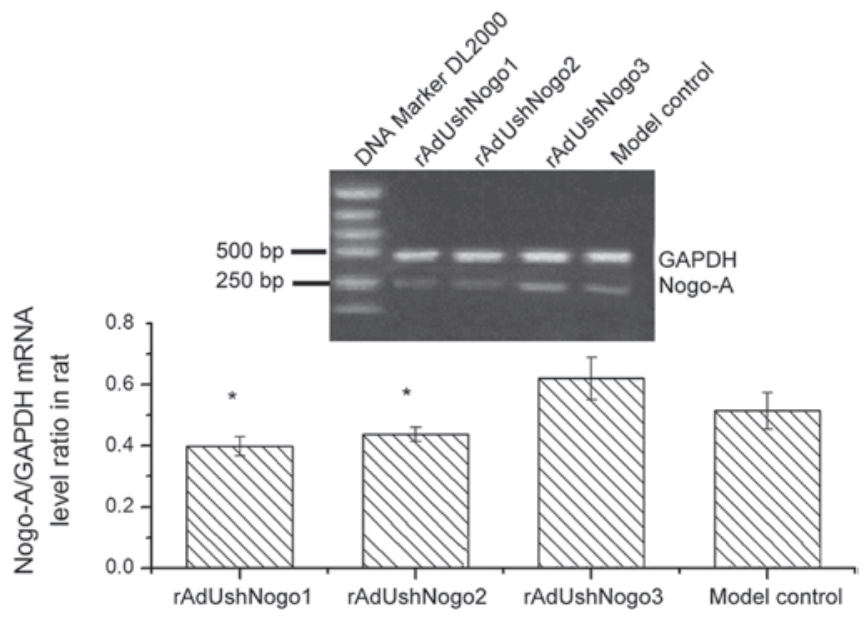

Figure 2. Reverse transcription-polymerase chain reaction analysis of Nogo-A mRNA expression following adenovirus-mediated Nogo shRNA transfection into rats with spinal cord injury. $\mathrm{P}<0.05$ compared with the rAdUshNogo3 (negative control) group. GAPDH, glyceraldehyde 3-phosphate dehydrogenase.

a polyvinylidene fluoride membrane. Consecutively, the membrane was blocked in 5\% skimmed milk (Inner Mongolia Yili Industrial Group Co., Ltd., Hohhot, China) in PBS-T at room temperature for $2 \mathrm{~h}$, incubated in either anti-Nogo-A (diluted 1:2,000; cat no. sc-25660) or anti-GAP-43 rabbit polyclonal antibodies (diluted 1:500; cat no. sc-10786) all purchased from Santa Cruz Biotechnology, Inc., (Dallas, TX, USA) overnight at $4^{\circ} \mathrm{C}$, incubated in horseradish peroxidase-conjugated anti-rabbit IgG (diluted 1:5,000; cat no. 31460; Thermo Fisher Scientific, Inc.) at room temperature for $1 \mathrm{~h}$, and visualized using enhanced chemiluminescence reagent. $\beta$-actin (diluted 1:5,000; cat no. sc-130656) was used as the housekeeping internal reference. Images were analyzed using Image-Pro Plus (version 6.0; Media Cybernetics Inc., Rockville, MD, USA).

In addition, the functional recovery of rats with SCI was assessed through the Basso, Beattie and Bresnahan (BBB) scoring system (26-30), 1, 2, 3, 4, 5, 6, 7, 8, 9 and 10 days after injection.

Statistical analysis. Data were analyzed using SPSS statistical software (version 17.0; SPSS, Chicago, IL, USA). Student's t-test and analysis of variance, with Duncan's multiple range test post-hoc analysis, were performed for comparison. $\mathrm{P}<0.05$ was considered to indicate a statistically significant difference.

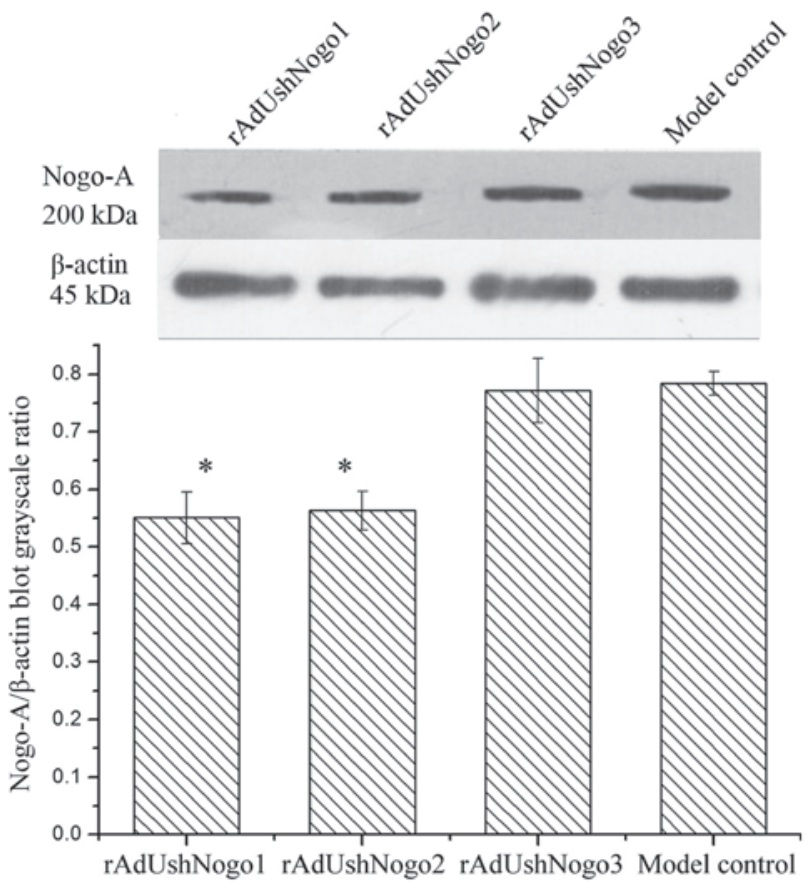

Figure 3. Western blot analysis of Nogo-A/ $\beta$-actin ratio of each group after the adenovirus-mediated Nogo shRNA was transfected into the rats with spinal cord injury. ${ }^{*} \mathrm{P}<0.05$, compared with rAdUshNogo3 (negative control) group.

\section{Results}

Construction of small hairpins with the U6 promoter. The upstream primer and the downstream primer with a reverse primer complementary target sequence of the U6 promoter were synthesized. The pShuttle-U6 was used as a template, U6F as upstream primers, hairpins 1,2 and 3 as the downstream primer. A 414 bp fragment with a U6 promoter and short hairpin loop was obtained (Fig. 1). U6shNogos were cut from the T vector with EcoRI and SalI, and then cloned into pDC316, to construct the pDCU6shNogo1, pDCU6shNogo2 and pDCU6shNogo3 plasmids. The 414 bp fragment was released by EcoRI and SalI restriction digestion, thus it was demonstrated that U6shNogos were properly inserted into the pDC316 plasmid.

Nogo-A mRNA levels in the rats with SCI following injection with rAdUshNogos. RT-PCR results showed that, compared with the rAdUshNogo3 group, Nogo mRNA relative expression levels of rAdUshNogol and rAdUshNogo2 groups were significantly reduced by $35.5 \%(\mathrm{P}<0.05)$ and $31.5 \%(\mathrm{P}<0.05)$, respectively. Compared with the model control, the expression level of Nogo mRNA in the oligodendrocytes of the rAdUshNogo3 group was not identified to be significantly different $(\mathrm{P}>0.05)$. Thus, the shRNAs were successfully transcribed in animals, and participated in the transcriptional regulation of the Nogo-A gene. shRNA interference in vivo effectively inhibited the expression of the Nogo-A gene, thus providing favorable conditions for regeneration of axons (Fig. 2).

Nogo-A protein blots of rats with SCI after injection with rAdUshNogos. Compared with the rAdUshNogo3 group (negative control), the relative expression of Nogo protein 

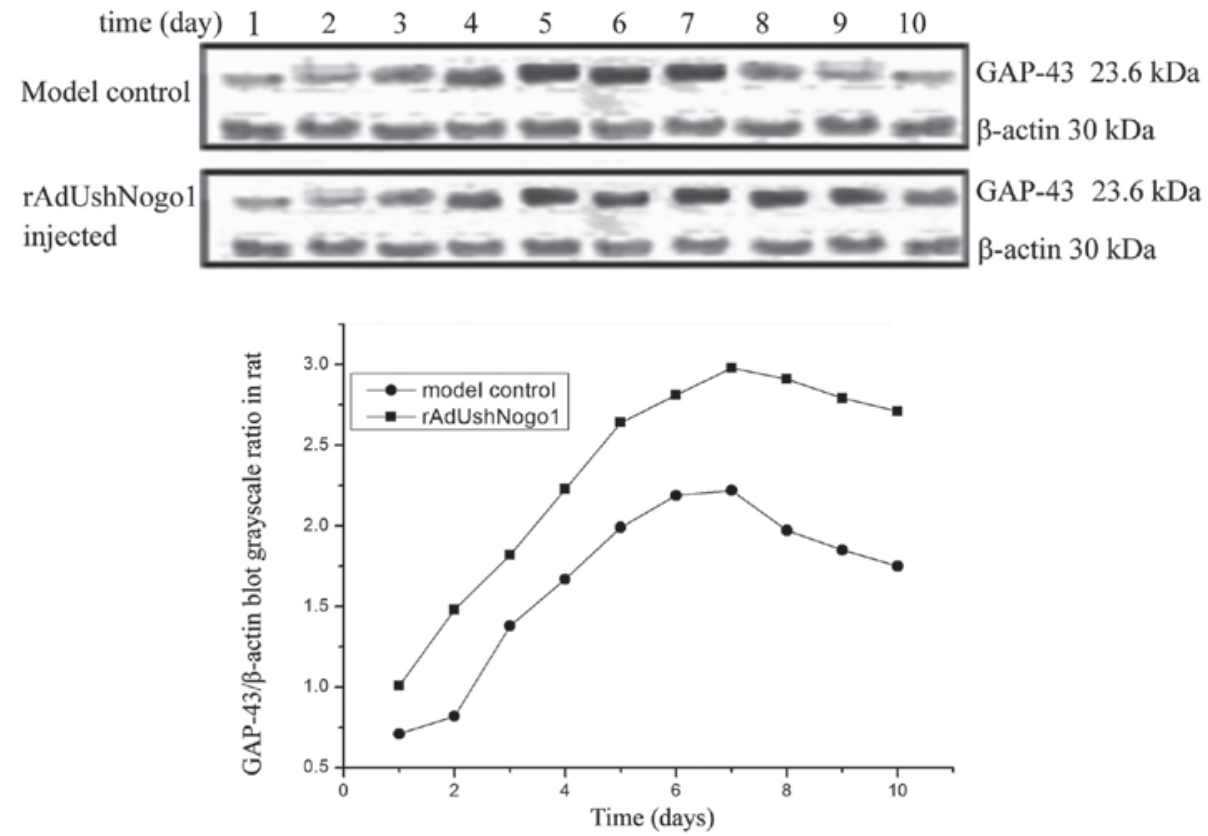

Figure 4. Western blot analysis of GAP-43 and $\beta$-actin for the model control and rAdUshNogol group. GAP-43, Growth associated protein 43.

in oligodendrocytes of rAdUshNogo1 group decreased by $29.5 \%(\mathrm{P}<0.05)$, and rAdUshNogo2 group decreased by $28.2 \%$ $(\mathrm{P}<0.05)$ (Fig. 3). The shRNAs inhibited Nogo-A expression at the protein level.

GAP-43 protein blots from rats with SCI following injection with rAdUshNogol. The GAP-43 expression levels in the model control and rAdUshNogol group increased. The GAP-43 expression level of the rAdUshNogol group was significantly increased, and reached the maximum at 7 days. After 2 days, the expression levels of GAP-43 in the rAdUshNogol group were markedly higher compared with the model control. After 7 days, the GAP-43 expression levels of the rAdUshNogol group and the model control reduced. However, the expression of GAP-43 in the rAdUshNogol group was not significantly reduced (Fig. 4).

Functional recovery of rats with SCI following injection with rAdUshNogol. The BBB scores (0-21 points) of the rats were determined using a double-blind method as reported in the literature (31). A lower score indicated more serious injury. Prior to spinal cord hemisection surgery, all rats achieved 21 points in the BBB tests. One day following hemisection, the $\mathrm{BBB}$ scores were $\sim 1$ for all rats. The BBB scores were significantly increased in the rAdUshNogol group on days 6, 8, $10(\mathrm{P}<0.05$; Fig. 5) compared with the model control.

\section{Discussion}

The spinal cord has a limited capacity for regeneration and this is largely attributable to the presence of cellular substrates that are unsuitable for growth. In vitro and in vivo evidence supports the ability of Nogo-A to inhibit neurite outgrowth (15,32-34).

In the present study, an animal model of SCI was generated, and virus-mediated small hairpin RNAs were injected into the spinal cord region by local injection. Nogo expression in

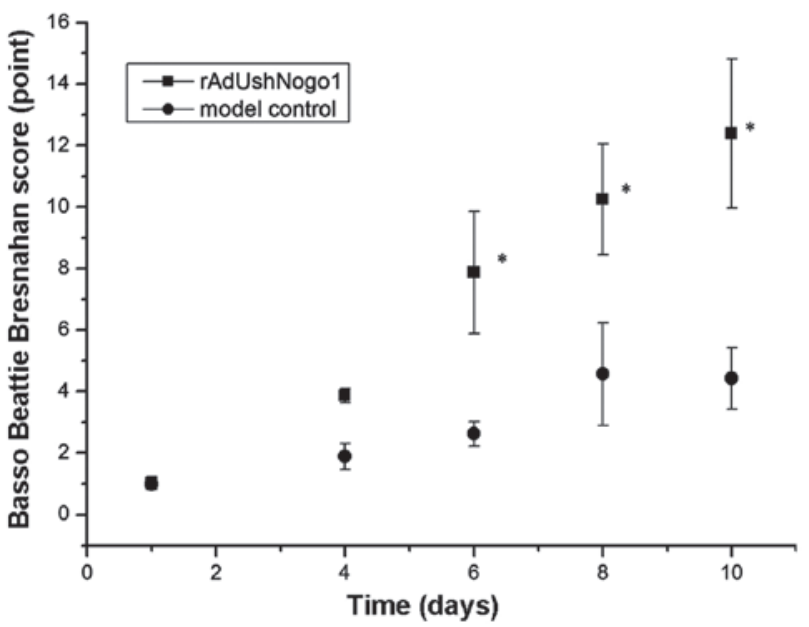

Figure 5. Basso, Beattie and Bresnahan scores in rats with spinal cord hemisection. Data are expressed as the mean \pm standard deviation, $n=4$. A lower score indicates a more serious injury. ${ }^{*} \mathrm{P}<0.05$ vs. the model control using Student's t-test.

the SCI region was detected by RT-PCR analysis. Compared with the rAdUshNogo3 group (negative control), Nogo mRNA relative expression levels in the SCI region decreased by $45.0 \%(\mathrm{P}<0.05)$ following injection with $\mathrm{rAdUshNogol}$ and $40.0 \%$ following injection with rAdUshNogo $2(\mathrm{P}<0.05)$. This indicated that the adenoviral vector that was constructed in vivo successfully transcribed short hairpin RNAs, which participated in Nogo-transcriptional regulation. rAdUshNogol and rAdUshNogo2 effectively suppressed the expression of the Nogo-A gene in vivo, and rAdUshNogo3 did not inhibit Nogo-A gene expression, indicating that the designed small hairpins were specific.

GAP-43 is a specific phosphoprotein of neural tissue. It is located in neurons, regenerated Schwann cells and glial cells, 
and is considered as the molecular marker of axon growth and plasticity $(35,36)$. High expression of GAP-43 is considered to be typical in the repair of nerves, and is closely associated with neuronal growth within the spinal cord $(37,38)$. In the process of neuronal growth, GAP-43 may affect axon growth by altering $\mathrm{G}$ protein activity of the growth cones, which guide axonal extension and growth. The interaction of $\mathrm{G}$ protein with its receptor generates inhibitory signals, resulting in the growth arrest of growth cones (39). When GAP-43 and G-protein bind, the disinhibition signal allows the axons to continue growth (39).

In the present study, GAP-43 expression in the spinal cord was increasing following SCI, indicating that GAP-43 participated in the growth and repair of the spinal cord. shRNAs against Nogo-A were injected into the rats with SCI. The experimental animals were divided into the rAdUshNogol group and the model control. The rAdUshNogol group underwent injection with rAdUshNogol for different time points of 1 to 10 days. The relative GAP-43 expression was detected by western blotting, with $\beta$-actin was used as a control. The results showed that, GAP-43 expression increased with time and reached a peak at 7 days. The GAP-43 expression of the rAdUshNogol group and the model control gradually increased, but the GAP-43 expression of the rAdUshNogo1 group was markedly higher than that of the model control. The BBB scores of the rAdUshNogol group were significantly higher than those of the model control after 6 days, indicating that the virus-mediated small hairpin was effectively transcribed in vivo and inhibited the expression of Nogo gene, which promoted axonal regeneration.

In conclusion, the adenoviral vector-mediated Nogo shRNA interference can effectively inhibit the expression of Nogo-A in oligodendrocytes and in rats with SCI, and upregulate the production of GAP-43 in rats with SCI. Knockdown by Nogo shRNAs has the potential to become an effective method for the treatment of SCI.

\section{References}

1. Chytrova G, Ying Z and Gomez-Pinilla F: Exercise normalizes levels of MAG and Nogo-A growth inhibitors after brain trauma. Eur J Neurosci 27: 1-11, 2008.

2. Filbin MT: Myelin-associated inhibitors of axonal regeneration in the adult mammalian CNS. Nat Rev Neurosci 4: 703-713, 2003.

3. Chaudhry N and Filbin MT: Myelin-associated inhibitory signaling and strategies to overcome inhibition. J Cereb Blood Flow Metab 27: 1096-1107, 2007.

4. Lenzlinger PM, Shimizu S, Marklund N, Thompson HJ, Schwab ME, Saatman KE, Hoover RC, Bareyre FM, Motta M, Luginbuhl A, et al: Delayed inhibition of Nogo-A does not alter injury-induced axonal sprouting but enhances recovery of cognitive function following experimental traumatic brain injury in rats. Neuroscience 134: 1047-1056, 2005.

5. Chen MS, Huber AB, van der Haar ME, Frank M, Schnell L, Spillmann AA, Christ F and Schwab ME: Nogo-A is amyelin-associated neurite outgrowth inhibitor and an antigen for monoclonal antibody IN-1. Nature 403: 434-439, 2000.

6. Fournier AE, GrandPre T and Strittmatter SM: Identification of a receptor mediating Nogo-66 inhibition of axonal regeneration. Nature 409: 341-346, 2001.

7. GrandPré T, Nakamura F, Vartanian T and Strittmatter SM: Identification of the Nogo inhibitor of axon regeneration as a Reticulon protein. Nature 403: 439-444, 2000.

8. Prinjha R, Moore SE, Vinson M, Blake S, Morrow R, Christie G, Michalovich D, Simmons DL and Walsh FS: Inhibitor of neurite outgrowth in humans. Nature 403: 383-384, 2000.
9. Liu BP,Cafferty WB, Budel SO and Strittmatter SM: Extracellular regulators of axonal growth in the adult central nervous system. Philos Trans R Soc Lond B Biol Sci 361: 1593-1610, 2006.

10. Domeniconi M, Cao Z, Spencer T, Sivasankaran R, Wang K, Nikulina E, Kimura N, Cai H, Deng K, Gao Y, et al: Myelin-associated glycoprotein interacts with the nogo66 receptor to inhibit neurite outgrowth. Neuron 35: 283-290, 2002.

11. Otori Y, Wei JY and Barnstable CJ: Neurotoxic effects of low doses of glutamate on purified rat retinal ganglion cells. Invest Ophthalmol Vis Sci 39: 972-981, 1998.

12. Ahmed Z, Dent RG, Suggate EL, Barrett LB, Seabright RJ, Berry M and Logan A: Disinhibition of neurotrophin-induced dorsal root ganglion cell neurite outgrowth on CNS myelin by siRNA-mediated knockdown of NgR, p75NTR and Rho-A. Mol Cell Neurosci 28: 509-523, 2005.

13. Acevedo L, Yu J, Erdjument-Bromage H, Miao RQ, Kim JE, Fulton D, Tempst P, Strittmatter SM and Sessa WC: A new role for Nogo as a regulator of vascular remodeling. Nat Med 10: 382-388, 2004.

14. Marklund N, Fulp CT, Shimizu S, Puri R, McMillan A, Strittmatter SM and McIntosh TK: Selective temporal and regional alterations of Nogo-A and small proline-rich repeat protein 1A (SPRR1A) but not Nogo-66 receptor $(\mathrm{NgR})$ occur following traumatic brain injury in the rat. Exp Neurol 197: 70-83, 2006.

15. Buchli AD and Schwab ME: Inhibition of Nogo: A key strategy to increase regeneration, plasticity and functional recovery of the lesioned central nervous system. Ann Med 37: 556-567, 2005.

16. Fouad K, Klusman I and Schwab ME: Regenerating corticospinal fibers in the Marmoset (Callitrix jacchus) after spinal cord lesion and treatment with the anti-Nogo-A antibody IN-1. Eur J Neurosci 20: 2479-2482, 2004.

17. Christman CW, Salvant JB Jr, Walker SA and Povlishock JT: Characterization of a prolonged regenerative attempt by diffusely injured axons following traumatic brain injury in the adult cat: A light and electron microscopic immunocytochemical study. Acta Neuropathol 94: 329-337, 1997.

18. Hulsebosch CE, DeWitt DS, Jenkins LW and Prough DS: Traumatic brain injury in rats results in increased expression of GAP-43 that corelates with behavioral recovery. Neurosci Lett 255: 83-86, 1998.

19. Emery DL, Royo NC, Fischer I, Saatman KE and McIntosh TK: Plasticity following injury to the adult central nervous system: Is recapitulation of a developmental state worth promoting? J Neurotrauma 20: 1271-1292, 2003.

20. Koda M, Hashimoto M, Murakami M, Yoshinaga K, Ikeda O, Yamazaki M, Koshizuka S, Kamada T, Moriya H, Shirasawa H, et al: Adenovirus vector-mediated in vivo gene transfer of brain-derived neurotrophic factor (BDNF) promotes rubrospinal axonal regeneration and functional recovery after complete transection of the adult rat spinal cord. J Neurotrauma 21: 329-337, 2004.

21. Zhao YY, Yuan Y, Chen Y, Jiang L, Liao RJ, Wang L, Zhang XN, Ohtsu $\mathrm{H}, \mathrm{Hu} \mathrm{WW}$ and Chen Z: Histamine promotes locomotion recovery after spinal cord hemisection via inhibiting astrocytic scar formation. CNS Neurosci Ther 21: 454-462, 2015.

22. Zhang Q, Shao Y,Zhao C, Cai J and Sun S: N-methyl-D-aspartate receptor antagonist MK-801 prevents apoptosis in rats that have undergone fetal spinal cord transplantation following spinal hemisection. Exp Ther Med 8: 1731-1736, 2014.

23. Latini L, Bisicchia E, Sasso V, Chiurchiù V, Cavallucci V, Molinari M, Maccarrone M and Viscomi MT: Cannabinoid CB2 receptor (CB2R) stimulation delays rubrospinal mitochondrial-dependent degeneration and improves functional recovery after spinal cord hemisection by ERK1/2 inactivation. Cell Death Dis 5: e1404, 2014.

24. Grosso MJ, Matheus V, Clark M, van Rooijen N, Iannotti CA and Steinmetz MP: Effects of an immunomodulatory therapy and chondroitinase after spinal cord hemisection injury. Neurosurgery 75: 461-471, 2014.

25. Yang J, Han Y, Ye W, Liu F, Zhuang K and Wu G: Alpha tocopherol treatment reduces the expression of Nogo-A and $\mathrm{NgR}$ in rat brain after traumatic brain injury. J Surg Res 182: e69-e77, 2013.

26. Yan M, Yang M, Shao W, Mao XG, Yuan B, Chen YF, Ye ZX, Liang W and Luo ZJ: High-dose ascorbic acid administration improves functional recovery in rats with spinal cord contusion injury. Spinal Cord 52: 803-808, 2014. 
27. Kaneko A, Matsushita A and Sankai Y: A 3D nanofibrous hydrogel and collagen sponge scaffold promotes locomotor functional recovery, spinal repair, and neuronal regeneration after complete transection of the spinal cord in adult rats. Biomed Mater 10: 015008, 2015.

28. Xian-Hui D, Xiao-Ping H and Wei-Juan G: Neuroprotective effects of the Buyang Huanwu decoction on functional recovery in rats following spinal cord injury. J Spinal Cord Med Oct 20, 2014 (Epub ahead of print)

29. Yamaya S, Ozawa H, Kanno H, Kishimoto KN, Sekiguchi A, Tateda S, Yahata K, Ito K, Shimokawa H and Itoi E: Low-energy extracorporeal shock wave therapy promotes vascular endothelial growth factor expression and improves locomotor recovery after spinal cord injury. J Neurosurg 121: 1514-1525, 2014.

30. Zhang J, Liu Z, Chen H, Duan Z, Zhang L, Chen L and Li B: Synergic effects of EPI-NCSCs and OECs on the donor cells migration, the expression of neurotrophic factors, and locomotor recovery of contused spinal cord of rats. J Mol Neurosci 55 760-769, 2015.

31. Basso DM, Beattie MS and Bresnahan JC: A sensitive and reliable locomotor rating scale for open field testing in rats. J Neurotrauma 12: 1-21, 1995.

32. Spencer T, Domeniconi M, Cao Z and Filbin MT: New roles for old proteins in adult CNS axonal regeneration. Curr Opin Neurobiol 13: 133-139, 2003
33. Schwab ME: Nogo and axon regeneration. Curr Opin Neurobiol 14: 118-124, 2004.

34. Filbin MT: Recapitulate development to promote axonal regeneration: Good or bad approach? Philos Trans R Soc Lond B Biol Sci 361: 1565-1574, 2006.

35. Wang XY and Zhang JT: Effects of ginsenoside $\operatorname{Rg} 1$ on synaptic plasticity of freely moving rats and its mechanism of action. Acta Pharmacol Sin 22: 657-662, 2001.

36. Hassiotis M, Ashwell KW, Marotte LR, Lensing-Höhn S and Mai JK: GAP-43 Immunoreactivity in the brain of the developing and adult wallaby (Macropus eugenii). Anat Embryol (Berl) 206: 97-118, 2002.

37. Tolner EA, van Vliet EA, Holtmaat AJ, Aronica E, Witter MP, da Silva FH and Gorter JA: GAP-43 mRNA and protein expression in the hippocampal and parahippocampal region during the course of epileptogenesis in rats. Eur J Neurosci 17: 2369-2380, 2003.

38. Carrasco J, Penkowa M, Giralt M, Camats J, Molinero A, Campbell IL, Palmiter RD and Hidalgo J: Role of metallothionein-III following central nervous system damage. Neurobiol Dis 13: 22-36, 2003.

39. McIlvain VA, Robertson DR, Maimone MM and McCasland JS: Abnormal thalamocortical pathfinding and terminal arbors lead to enlarged barrels in neonatal GAP-43 heterozygous mice. J Comp Neurol 462: 252-264, 2003. 